\title{
UPAYA MENINGKATKAN HASIL BELAJAR EKONOMI DENGAN MENGGUNAKAN MODEL PEMBELAJARAN TALKING STICK PADA SMA NEGERI 4 PALANGKA RAYA
}

\author{
Oleh \\ Ervini Agustini,* Supardi** \\ Email:supardi@yahoo.com
}

\begin{abstract}
This study aims to describe learning activities and improve learning outcomes. The method used in this study is to use a Classroom Action Research (CAR) design that seeks to overcome the problems faced in the current situation. The subjects needed in this study were students of class XI-10 Palangkaraya 4 High School, totaling 35 students, for data collection techniques used were observation and tests. Data analysis consists of qualitative and quantitative data. The results of the study show that: (1) Student learning activities are good. This is evidenced by the acquisition of the average score of learning activities of students in the first cycle obtaining an average score of 3.77 with the criteria of Good. (2) There is an increase in learning outcomes. This can be proven by the acquisition of the average score of the students in the pre-cycle there is no complete $(0.00 \%)$ got a value of engan 75 with unfavorable criteria. This is evidenced by the acquisition of the average score of learning activities of students in the first cycle obtaining an average score of 3.77 with completeness (100\%) or getting a value of $\geq 75$ with the criteria Good.
\end{abstract}

(C) Muhammadiyah University Palangkaraya

Keywords: Economic Learning Outcomes, and Talking Stick Learning Models

\begin{abstract}
ABSTRAK
Penelitian ini bertujuan untuk mendeskripsikan aktivitas belajar dan meningkatkan hasil belajar. Metode yang digunakan dalam penelitian ini adalah menggunakan rancangan Penelitian Tindakan Kelas (PTK) yang berusaha mengatasi permasalahan yang dihadapi pada situasi sekarang. Subjek yang dibutuhkan dalam penelitian ini, adalah peserta didik kelas XI-10 SMA Negeri 4 Palangka Raya yang berjumlah 35 orang peserta didik, untuk teknik pengumpulan data yang digunakan adalah observasi dan tes. Analisis data terdiri dari data kualitatif dan kuantitatif. Hasil penelitian menunjukan bahwa: (1) Aktivitas belajar peserta didik menjadi baik. Hal ini dibuktikan dengan perolehan skor rata-rata aktivitas belajar peserta didik pada siklus 1 memperoleh skor rata-rata 3,77 dengan kriteria Baik. (2) Ada peningkatan hasil belajar. Hal ini dapat di buktikan dengan adanya perolehan skor rata-rata peserta didik pada pra siklus tidak ada yang tuntas $(0,00 \%)$ mendapat nilai $\leq 75$ dengan kriteria kurang baik. Hal ini dibuktikan dengan perolehan skor rata-rata aktivitas belajar peserta didik pada siklus 1 memperoleh skor rata-rata 3,77 dengan ketuntasan (100\%) atau mendapat nilai $\geq 75$ dengan kriteria Baik.
\end{abstract}

(C) Universitas Muhammadiyah Palangkaraya

Kata Kunci: Hasil Belajar Ekonomi, dan Model Pembelajaran Talking Stick 


\section{PENDAHULUAN}

Berdasarkan Tujuan Pendidikan Nasional yang dirumuskan dalam Undang-Undang Repbulik Indonesia No.20/2004, (Sisdiknas 2005 : 6) tentang Sistem Pendidikan Nasional bahwa Pendidikan Nasional berfungsi mengembangkan kemampuan dan membentuk watak serta peradaban bangsa yang bermartabat, bertujuan untuk berkembangnya potensi peserta didik agar menjadi manusia beriman dan bertakwa kepada Tuhan Yang Maha Esa, berakhlak mulia, sehat, berilmu, cakap, kreatif, mandiri dan menjadi warga Negara yang demokratis serta bertanggung jawab. Jadi, Pendidikan Nasional berfungsi strategis dalam membentuk dan mengembangkan watak, perilaku dan peradaban bangsa serta merupakan suatu alat sekaligus tujuan yang terpenting dalam usaha pencapaian tujuan pembangunan nasional. Agar tujuan pendidikan nasional dapat tercapai dibutuhkan partisipasi aktif oleh semua unsur yang terkait dalam pelaksanaan pendidikan nasional tersebut.

Kegiatan pembelajaran dilakukan oleh dua pelaku, yaitu guru dan peserta didik. Perilaku guru adalah mengajar dan perilaku peserta didik adalah belajar. Pembelajaran merupakan suatu sistem, yang terdiri atas berbagai komponen yang saling berhubungan satu dengan yang lain. Komponen tersebut meliputi: tujuan, materi, metode, model dan evaluasi.

Menurut Dimyati dan Mudjiono, (2013 : 250) menyatakan hasil belajar merupakan hasil proses belajar. Pelaku aktif dalam belajar adalah peserta didik.
Hasil belajar juga merupakan hasil proses belajar, atau proses pembelajaran. Pelaku aktif pembelajaran adalah guru. Dengan demikian, hasil belajar merupakan hal yang dapat dipandang dari dua sisi siswa, hasil belajar merupakan tingkat perkembangan mental yang lebih baik bila dibandingkan pada pra-belajar. Tingkat perkembangan mental tersebut terwujud pada jenis-jenis ranah kognitif, afektif, dan psikomotor. Secara menyeluruh proses belajar berjalan dalam waktu beberapa tahun sesuai dengan jenjang sekolah. Sedangkan hasil belajar menurut Aunurrahman (2010:38) adalah perubahan hasil belajar dapat ditandai dengan perubahan kemampuan berpikir. Seorang guru yang mampu mengembangkan modelmodel pembelajaran yang terarah pada latihan-latihan berpikir kritis siswa akan sangat mendukung perubahan kemampuan berpikir siswa.

Menurut Sudjana menyatakan bahwa hasil belajar adalah kemampuan-kemampuan yang dimiliki peserta didik setelah ia menerima pengalaman belajarnya dan hasil belajar peserta didik pada hakekatnya adalah perunahan tingkah laku.

Secara sederhana yang dimaksud dengan hasil belajar peserta didik adalah kemampuan yang diperoleh anak setelah melalui kegiatan belajar. Karena belajar itu sendiri merupakan suatu proses dari seseorang yang berusaha untuk memperoleh suatu bentuk perubahan perilaku yang relatif menetap. Dalam kegiatan pembelajaran atau kegiatan instruksional, biasanya guru menetapkan tujuan belajar. Anak 
yang berhasil dalam belajar adalah yang bethasil mencapai tujuan- tujuan pembelajaran atau tujuan instruksional. Untuk mengetahui tingkat pemahaman peserta didik terhadap materi dalam pembelajaran adalah melihat hasil belajar peserta didik yang didapatkan selama proses pembelajaran berlangsung.

Pembelajaran merupakan komunikasi dua arah, mengajar dilakukan oleh pihak guru sebagai pendidik, sedangkan belajar dilakukan oleh peserta didik. Pembelajaran didalamnya mengandung makna belajar dan mengajar, atau merupakan kegiatan belajar mengajar. Belajar tertuju kepada apa yang harus dilakukan oleh seseorang sebagai subjek yang menerima pelajaran, sedangkan mengajar berorientasi pada apa yang harus dilakukan oleh guru sebagai pemberi pembelajaran. Pembelajaran dalam pandangan Corey sebagai upaya menciptakan kondisi dan lingkungan belajar yang kondusif sehingga memungkinkan peserta didik berubah tingkah lakunya. Pembelajaran berarti aktivitas guru dalam merancang bahan pengajaran agar proses pembelajaran dapat berlangsung secara efektif, yakni siswa dapat belajar secara aktif dan bermakna.

Secara umum ilmu ekonomi adalah ilmu yang mempelajari cara individu dan masyarakat mempelajari perihal pilihan dan keputusan yang dilakukan setiap orang dalam memobilisasi dan mengalokasikan sumber ekonomi yang jumlahnya terbatas terhadap alat pemuas kebutuhan manusia yang tidak terbatas.
Penerapan kegiatan ekonomi sebenarnya telah kita praktikkan dalam kehidupan sehari-hari seperti kegiatan menabung, berbelanja kebutuhan, dan menggunakan uang secara bijak. Adapun tujuan dari penerapan pembelajaran ekonomi. Wonnacott, seorang ekonom Amerika Serikat, memberikan penjelasan tentang tujuan manusia mempelajari ilmu ekonomi. Penerapan ilmu ekonomi diharapkan mampu menjawab berbagai permasalahan ekonomi yang berkaitan dengan pemenuhan kebutuhan manusia.

Menurut Anni (2010: 5) menjelaskan bahwa hasil belajar ekonomi merupakan perubahan yang diperoleh pembelajaran setelah mengalami aktivitas belajar. Peroleh perubahan perilaku tersebut tergantung apa yang dipelajari oleph siswa, apabila siswa mempelajari pengetahuan tentang konsep maka perubahan perilaku yang diperoleh adalah pengetahuan tentang konsep. Sedangkan Menurut Ahmad (2013: 5) menyatakan bahwa hasil belajar ekonomi peserta didik adalah perubahan-perubahan yang terjadi pada diri peserta didik, baik yang menyangkut aspek kognitif, afektif, dan psikomotorik sebagai hasil dari kegiatan belajar.

Hasil belajar yaitu perubahanperubahan yang terjadi pada diri peserta didik, baik yang menyangkut aspek kognitif, afektif, dan psikomotor sebagai hasil dari kegiatan belajar. Untuk mengetahui apakah hasil belajar yang dicapai telah sesuai dengan tujuan yang dikehendaki dapat diketahui melalui evaluasi. Sebagaimana dikemukakan oleh Sunal (Ahmad 
Susanto, 2013: 5) bahwaevaluasi merupakan proses penggunaan informasi untuk membuat pertimbangan seberapa efektif suatu program telah memenuhi kebutuhan peserta didik. Selain itu, dengan dilakukannya evaluasi atau penilaian ini dapat dijadikan feedback atau tindak lanjut, atau bahkan cara untuk mengukur tingkat penguasaan peserta didik.

Dari pendapat di atas maka dapat disimpulkan bahwa evaluasi merupakan proses penilaian suatu objek berdasarkan kriteria tertentu, dan sistematis dalam membandingkan hasil yang dicapai dengan tolak ukur yang telah ditetapkan kemudian dibuat suatu kesimpulan dan penyusunan saran pada setiap tahap dari pelaksanaan program.

Pembelajaran yang digunakan seseorang dalam menyampaikan materi mata pelajaran kepada peserta didik sangat menentukan dalam menyampaikan tujuan pembelajaran. Sering kita jumpai masih banyaknya proses belajar mengajar di kelas yang kurang mendorong peserta didik untuk bersemangat mengikuti pelajaran.

Model pembelajaran pada hakikatnya merupakan salah satu bagian dari keseluruhan sistem belajar yang tidak dapat dipisahkan dari sistem lainnya. Model pembelajaran dapat diartikan sebagai prosedur sistematis dalam mengorganisasikan pengalaman belajar untuk mencapai tujuan belajar.

Menurut Amri (2013: 7) berpendapat bahwa: Model pembelajaran adalah suatu pola atau langkah-langkah pembelajaran dari hasil belajar yang diharapkan dapat tercapai dengan lebih efektif dan efesien. Sedangkan Menurut Menurut Joyce dan Weil (Rusman, 2013: 133) berpendapat bahwa model pembelajaran adalah suatu rencana atau pola yang dapat digunakan untuk membentuk kurikulum (rencana pembelajaran jangka panjang), merancang bahan-bahan pelajaran, dan membimbing pembelajaran di kelas atau yang lain. Dari berbagai pendapat para ahli tersebut dapat disimpulkan bahwa model pembelajaran merupakan suatu perencanaan yang digunakan sebagai prosedur dalam proses belajar mengajar untuk mencapai tujuan pembelajaran.

Model Pembelajaran Kooperatif (Cooperative Learning) merupakan model pengajaran dimana peserta didik belajar dalam kelompok kecil yang memiliki kemampuan yang berbeda. Menurut Huda (2013: 111) menyatakan bahwa salah satu asumsi yang mendasari pengembangan pembelajaran Kooperatif (Cooperative Learning) adalah bahwa sinergi yang muncul melalui kerja sama akan meningkatkan motivasi yang jauh lebih besar daripada lingkungan kooperative individual. Pembelajaran kooperatif adalah siswa belajar bersama dalam kelompok yang terdiri dari 4-5 orang peserta didik dengan latar belakang jenis kelamin, suku, agama, ras, sosial dan kepribadian yang beranekaragam. Setiap anggota bertanggung jawab terhadap tugas yang diberikan. Kebersamaan dalam belajar akan dapat menimbulkan motivasi, produktivitas dan perolehan pencapaian. Subyantoro

(2007:15) mengatakan bahwa model talking stick (tongkat berbicara) adalah model pembelajaran dengan bantuan tongkat, 
siapa yang memegang tongkat wajib menjawab pertanyaan dari pendidik setelah peserta didik mempelajari materi pokoknya. Talking stick mendorong peserta didik untuk berani mengemukakan pendapat.

Anggraini (dalam Sudjana 2014:12) mengatakan bahwa model pembelajaran Talking Stick adalah model pembelajaran yang menggunakan alat berupa tongkat sebagai alat bantu bagi guru untuk mengajukan pertanyaan kepada peserta didik dengan menimbulkan suasana yang menyenangkan. Tongkat tersebut digilirkan pada peserta didik dan bagi peserta didik mendapatkan tongkat sesuai dengan aba-aba dari guru, maka peserta didik diberi pertanyaan oleh guru dan harus menjawab

Model pembelajaran Talking Stick merupakan model pembelajaran kelompok dengan bantuan tongkat. Peserta didik yang memegang tongkat terlebih dahulu menjawab pertanyaan dari guru setelah mereka mempelajari materi pokoknya terlebih dahulu. Kegiatan ini diulang terus-menerus sampai peserta didik yang lain mendapat giliran untuk menjawab pertanyaan dari guru. Dengan menggunakan model pembelajaran Talking Stick peserta didik diharapkan menjadi aktif dan bersemangat dalam kegiatan belajar mengajar, jika peserta didik aktif, maka mereka akan memperhatikan penjelasan materi dengan seksama dan kreatif, sehingga pembelajaran lebih hidup. Dalam hal ini model pembelajaran yang menarik dan membuat peserta didik aktif dan kreatif.
Keberadaan model dan media pembelajaran diperlukan untuk membantu tugas-tugas guru. Guru memiliki tugas yang sangat penting guna menciptakan kondisi pembelajaran yang efektif sehingga memungkinkan proses pembelajaran dapat dicapai tujuan yang baik. Salah satu kompetisi profesional yang harus dimiliki seorang guru adalah guru harus dapat memilih, mengembangkan dan menggunakan model pembelajaran. Hal ini penting karena dapat membantu para guru dan staf pengajar dalam menyapaikan pesan pembelajaran lebih cepat dan lebih mudah ditangkap oleh peserta didik. Model pembelajaran memiliki kekuatan-kekuatan yang positif dan sinergi yang mampu merubah sikap dan perilaku, hasilnya mereka kearah perubahan kreatif dan dinamis. Sehubungan dengan hal itu, model pembelajaran seperti model pembelajaran Talking Stick sangat dibutuhkan dalam pembelajaran bukan lagi dipandang sekedar alat bantu tetapi merupakan bagian yang integral dalam sistem pendidikan dan pembelajaran.

Dan selain itu, berdasarkan informasi dari guru pengampu mata pelajaran ekonomi bahwa kondisi belajar peserta didik tersebut berdampak pada hasil belajar dan sebagian peserta didik yang belum mencapai KKM (Kriteria Ketuntasan Minimun), dimana KKM yang ditentukan sebesar 75, dari 35 peserta didik hanya 18 peserta didik yang mencapai KKM.

Maka peneliti disini berusaha mencoba untuk memecahkan suatu permasalahan dengan menggunakan 
model pembelajaran Talking Stick yang menuntut keaktifan peserta didik, tidak membosankan, serta tidak malas dalam proses pembelajaran. Sehingga diharapkan berdampak kepada hasil belajar yang memuaskan artinya mampu mencapai nilai KKM yakni 75 yang berlaku di sekolah SMA Negeri 4 Palangka Raya.

Berdasarkan latar belakang tersebut maka peneliti bertujuan untuk melakukan sebuah penelitian tindakan kelas dengan judul “ Upaya Meningkatkan Hasil Belajar Ekonomi Dengan Menggunakan Model Pembelajaran Talking Stick Pada SMAN 4 Palangka Raya.

\section{METODE PENELITIAN}

Dalam penelitian ini jenis penelitian yang digunakan untuk meningkatkan hasil belajar peserta didik yaitu penelitian tindakan kelas. Penelitian Tindakan Kelas adalah penelitian tindakan (action research) yang dilakukan dengan tujuan memperbaiki mutu praktik pembelajaran dikelas.

Suharsimi Arikuto (2009:58) menjelaskan PTK melalui paparan gabungan definisi dari tiga kata yaitu :

1. Penelitian adalah kegiatan mencermati suatu obyek, menggunakan aturan metodologi tertentu unutk memperoleh data atau informasi yang bermanfaat untuk meningkatkan mutu suatu hal yang menarik minat dan penting bagi peneliti.

2. Tindakan adalah sesuatu gerak kegiatan yang sengaja dilakukan dengan tujuan tertentu, yang dalam penelitian berbentuk rangkaian siklus kegiatan.

3. Kelas adalah sekolompok peserta didik dalam waktu yang sama menerima pelajaran yang sama dari seorang guru.

Penelitian lain dikemukakan oleh Kunandar (2012:46) bahwa penelitian tindakan kelas adalah suatu penelitian yang berbasis pada kelas. Penelitian dapat dilakukan secara mandiri, tetapi alangkahnya baiknya kalau dilaksanakan secara kolaboratif, baik dengan teman sejawat, kepala sekolah, pengawas, dosen, pihak, lain yang relevan dengan PTK.

Dalam penelitian ini yang menjadi subyek penelitian adalah peserta didik kelas XI-10 SMAN 4 Palangkaraya yang terdiri dari 35 peserta didik dengan komposisi peserta didik perempuan, dan peserta didik laki-laki. Peneliti memilih subyek penelitian ini karena ditemui ada beberapa peserta didik yang kurang aktif dan hasil belajarnya masih rendah.

Penelitian Tindakan Kelas (PTK) merupakan suatu penelitian yang dilakukan untuk mengamati suatu obyek, yang dilakukan di dalam kelas dengan tujuan untuk memperbaiki atau meningkatkan mutu praktik pembelajaran.

\section{HASIL PEMBAHASAN}

Hasil belajar peserta didik dengan di tentukannya kriteria ketuntasan minimal (KKM) 75, dalam penelitian ini hasil belajar yang di peroleh dari nilai pre test peserta didik yang tuntas tidak ada $(0 \%)$ dan setelah di berikan tindakan dengan menerapkan model 
pembelajaran Talking Stick pada siklus peserta didik yang tuntas atau mendapat nilai di atas KKM yaitu 100\% (35 peserta didik). Maka ketuntasan belajar peserta didik sudah mencapai ketuntasan klasikal, sehingga tidak perlu di lanjutkan ke siklus II.

Aktivitas peserta didik dalam pembelajaran Ekonomi dengan menerapkan Model Pembelajaran Talking Stick pada siklus I memperoleh skor rata-rata 3,77 dan termasuk dalam kategori baik.

Hasil belajar peserta didik setelah Menggunakan Model Pembelajaran Talking Stick terjadi peningkatan. Dapat di ketahui bahwa hasil belajar peserta didik dari test awal (pre test) sampai dengan siklus I, dari 35 peserta didik pada test awal (Pre test) tidak ada peserta didik yang tuntas. Jumlah peserta didik yang tidak tuntas pada test awal (pre test) ada 35 peserta didik, siklus I yang tidak tuntas tidak ada.

Sesuai dengan data temuan hasil belajar analisis aktivitas dan peningkatan hasil belajar peserta didik setelah dilakukan perbaikan dengan menerapkan Model Pembelajaran Talking Stick, terbukti dapat mencapai hasil yang lebih baik dari sebelumnya. Pada pelaksanaan peningkatan hasil belajar peserta didik dalam pembelajaran Ekonomi ini terbukti telah terjadi peningkatan dari kondisi awal pre test tidak ada yang tuntas $(0,00 \%)$, post test (siklus I) yang tuntas 35 peserta didik (100\%).

Penelitian ini hanya 1 siklus adalah hasil belajar peserta didik dan di tentukannya kriteria ketuntasan minimal $(\mathrm{KKM}) 75$, dalam penelitian ini hasil belajar yang di peroleh dari nilai pre test peserta didik yang tuntas tidak ada (0\%) dan setelah di berikan tindakan dengan menggunakan model pembelajaran Talking Stick pada siklus ini peserta didik yang tuntas atau mendapat nilai di atas KKM yaitu 100\% (35 peserta didik). Maka ketuntasan belajar peserta didik sudah mencapai ketuntasan klasikal, sehingga tidak perlu di lanjutkan ke siklus.

\section{KESIMPULAN}

Dari penelitian dan pembahasan pada siklus I, maka dapat diambil kesimpulan sebagai berikut :

1. Aktivitas belajar peserta didik dengan menggunakan model Pembelajaran Talking Stick mengalami peningkatan dalam proses pembelajaran ekonomi, peserta didik aktif saat pembelajaran berlangsung. Siklus I aktivitas belajar peserta didik diperoleh skor rata-rata 3,77 dengan kategori baik.

2. Ada peningkatan hasil belajar Ekonomi peserta didik dengan menggunakan Model Pembelajaran Talking Stick pada peserta didik kelas XI-10 SMA Negeri 4 Palangka Raya. Pada siklus I adanya peningkatan hasil belajar peserta didik yaitu dengan nilai rata-rata 87,28 dengan ketuntasan klasikal persentase $100 \%$ atau (35 orang) peserta didik telah mencapai KKM. Dengan demikian dapat disimpulkan bahwa ada peningkatan hasil belajar dengan menggunakan model pembelajaran Talking Stick. 


\section{DAFTAR PUSTAKA}

Ahmad Susanto. (2013), Teori Belajar dan Pembelajaran. Jakarta: Kencana PRENADA Media Group

Amri, sofan. (2013). Pengembangan \& Model Pembelajaran Dalam Kurikulum 2013. Jakarta: Prestasi Pusaka karya

Aunurrahman. (2010), Belajar dan Pembelajaran. Bandung : Alfabetha

Dimyati dan Mudjiono. (2013), Belajar dan Pembelajaran, Jakarta : PT Rineka Cipta

Kunandar. (2012), Langkah-Langkah Penelitian Tindakan Kelas. Jakarta : Rajawali Pers

Rusman, (2013), Model-Model Pembelajaran: Mengembangkan Profesionalisme Guru, Jakarta: Rajawali Pers

Sudjana. (2010). Dasar-dasar Proses Belajar. Bandung: Sinar Baru Trianto. (2014). Model Pembelajaran Terpadu. Jakarta: PT Bumi Aksara

Undang-Undang RI, (2003), Tentang Sistem Pendidikan Nasional. Bandung: Citra Umbara. 